\title{
Presence of diminutive hadrosaurids (Dinosauria: Ornithopoda) in the Maastrichtian of the south-central Pyrenees (Spain)
}

\author{
J. Company ${ }^{1 *}$, P. Cruzado-Caballero ${ }^{2,3}$, J.I. Canudo ${ }^{3}$ \\ ${ }^{1}$ Departamento de Ingeniería del Terreno, Universidad Politécnica de Valencia, Camino de Vera s/n, 46022 Valencia, Spain. \\ ${ }^{2}$ Instituto de Investigación en Paleobiología y Geología, Universidad Nacional de Río Negro, Isidro Lobo y Belgrano, \\ 8332 General Roca, Río Negro, Argentina. \\ ${ }^{3}$ Grupo Aragosaurus-IUCA, Departamento de Ciencias de la Tierra, Facultad de Ciencias, Universidad de Zaragoza. c/ \\ Pedro Cerbuna 12, 50009 Zaragoza, Spain.
}

e-mail addresses: company@uv.es (J.C., *corresponding autor); pccaballero@unrn.edu.ar (P.C.C.); jicanudo@unizar.es (J.I.C.)

Received: 8 January 2014 / Accepted: 18 December 2014 / Available online: 25 March 2015

\begin{abstract}
In recent years a rich and diverse fauna of hadrosaurid dinosaurs has been described in the Upper Cretaceous of the Pyrenees. Recent fieldwork carried out in the upper Maastrichtian levels of the Tremp Formation, in the south-central Pyrenees (province of Huesca, northeastern Spain), has allowed us to recover diminutive fossil bones referable to hadrosaurid dinosaurs. To date, small-sized specimens had not been reported in the area. The remains consist of small vertebrae and fragmentary long bones found in a relatively small area, so it is assumed that they probably belong to individuals of a single population. A morphological examination and a histological study reveal that they represent specimens of advanced ontogenetic stage and allow the identification of an undescribed taxon of small-bodied hadrosaurids. In other parts of Europe, discoveries of small dinosaurs have been linked to insularity. These findings bring to light the smallest hadrosaurid known in Europe to date.
\end{abstract}

Keywords: hadrosaurids, bone histology, dwarfism, Maastrichtian, Pyrenees, Iberian Peninsula

\begin{abstract}
Resumen
En los últimos años se ha descrito una abundante y variada fauna de dinosaurios hadrosáuridos en el Cretácico superior de los Pirineos. Recientes trabajos de campo llevados a cabo en niveles del Maastrichtiense superior de la formación Tremp, en los Pirineos meridionales (provincia de Huesca, España), han permitido recuperar pequeños restos fósiles de dinosaurios hadrosáuridos. Hasta el momento, no habían sido descritos en la región especímenes de dinosaurios de pequeño tamaño. Los restos consisten en pequeñas vértebras y fragmentos de huesos largos, localizados en un área reducida, por lo que se asume que probablemente pertenecieron a individuos de una misma población. El examen morfológico de los restos y su estudio histológico revelan que representan individuos en un estado ontogenético avanzado, lo que permite su asignación a un taxón de hadrosaurios enanos no descrito previamente. En otras partes de Europa, la presencia de dinosaurios de talla reducida ha sido relacionada con fenómenos de insularidad. Estos hallazgos sacan a la luz el hadrosáurido más pequeño conocido en Europa hasta la fecha.
\end{abstract}

Palabras clave: hadrosáuridos, histología, enanismo, Maastrichtiense, Pirineos, Península Ibérica

\section{Introduction}

Franz Baron Nopcsa pointed out in 1914 that the recently discovered Late Cretaceous vertebrate fauna of Transylvania inhabited an insular domain (Nopcsa, 1914). Nopcsa also realized that the dinosaurs from Transylvania were scaled-down versions of their relatives from the mainland, and regarded insular isolation as the cause of the dwarfism and the primitive character of the Transylvanian dinosaur fauna (Nopcsa,
1914, 1923). Ever since a controversy has revolved around the cause of the reduced size of the dinosaurs that lived on islands (Pereda-Suberbiola and Galton, 2009; Benton et al., 2010, and references therein). Nowadays, palaeogeographic studies confirm the insular configuration of the European scenario during the Late Cretaceous (Philip et al., 2000; Blakey 2001), and additional remains of small-bodied dinosaurs have been recovered from other landmasses of the European Archipelago, but frequently in association with larger forms 
(Pereda-Suberbiola and Galton, 2009). Following Nopcsa's concept, insularity has been recently proposed as a way of interpreting the small size of certain "insular" European dinosaurs such as Europasaurus holgeri from the Upper Jurassic of Germany (Sander et al., 2006) or Telmatosaurus transsylvanicus, Magyarosaurus dacus, and Zalmoxes species from the Maastrichtian of Romania (Weishampel et al., 2003; Benton et al., 2010; Stein et al., 2010). Nevertheless, a full explanation for the reduced size of these diminutive dinosaurs remains elusive, mainly because the "island effect" alone cannot explain the coexistence of large and small dinosaur taxa on the same landmasses (Le Loeuff, 2005; PeredaSuberbiola and Galton, 2009; Stein et al., 2010) unless this faunal mixture is considered to be due to the presence of immigrant populations (Benton et al., 2010; Stein et al., 2010).

The Ibero-Armorican Island (Iberian Peninsula and southern France) was probably one of the largest landmasses of the European Archipelago in the uppermost Cretaceous (Le Loeuff, 1991). The composition of its dinosaur faunas is complex: there are endemic and migrant species, at least among some of the European islands in certain temporal intervals. In recent years, an effort has been made to understand the origin and evolution of European hadrosaurids, with the demonstration that part of the faunas are migrants (Pereda-Suberbiola et al., 2009a; Prieto-Márquez et al., 2013; Cruzado-Caballero et al., 2014). The large size of the Ibero-Armorican Island could have reduced the influence of the "island effect" on the fauna. In fact, Late Cretaceous Ibero-Armorican localities have yielded a continental fauna dominated by medium-to-largesized dinosaurs, such as the sauropods Ampelosaurus atacis, Lirainosaurus astibiae (Le Loeuff, 1995; Sanz et al., 1999) and the hadrosaurids Arenysaurus ardevoli, Blasisaurus canudoi and Pararhabdodon isonensis (Casanovas-Cladellas et al.,1993; Pereda-Suberbiola et al., 2009b; Cruzado-Caballero et al., 2010), as well as a number of indeterminate largeand small-sized sauropod titanosaurs (Vila et al., 2012). At present, only one small-sized taxon has been documented, the nodosaurid Struthiosaurus sp. (Pereda-Suberbiola, 1999).

Recent fieldworks undertaken in upper Maastrichtian exposures of Huesca Province (Spanish Pyrenees) have produced fossil remains of a very small hadrosaurid dinosaur for the first time in the Iberian Peninsula. The main objective of this study is to characterize the bone histology of representative elements such as a humerus and a femur of these small-sized hadrosaurids, and to assess the ontogenetic status of the individuals.

\section{Geology and stratigraphy}

The vertebrate fossil sites mentioned in this study are located near the villages of Serraduy del Pon and Beranuy, in the central-southern Pyrenees (NE Huesca, Spain, Fig. 1). They are situated in the northern flank of the Tremp syncline (Tremp Basin) within the South Pyrenean Central Unit. The dinosaur-bearing beds of this area belong to the upper part of the Arén Sandstone Formation and to the lower and middle part of the Tremp Formation. The Arén Sandstone Formation is overlain by and interfingered with the lowermost part of the Tremp Formation in the Tremp Basin. The Arén Sandstone Formation consists of beach, barrier-island and deltaic system deposits of Late Campanian to Early Maastrichtian age (references in Riera et al., 2009). The Tremp Formation (Tremp Group for several authors) is composed of continental and transitional deposits from the upper part of the Cretaceous and lower part of the Tertiary. The dinosaur remains in the Serraduy area come from the lower and middle part of the Tremp Formation, identified as the "Posa and Conques Formations" by several authors (Puértolas-Pascual et al., 2012; Vila et al., 2012, 2013). The lower part of the Tremp group is referred to by other authors as the grey unit and the lower red unit (Riera et al., 2009). The grey unit in the SerraduyBeranuy area is composed of marine-continental transitional sediments mainly consisting of sandstone and grey marls containing invertebrate fossils. The lower red unit includes red mudstones, sandstones, microconglomerates and palaeosols of fluvial facies.

Vertebrate fossils (bones and ichnites) are abundant in the grey and the lower red units. The fossil bones are usually found in sandstone and, more frequently, in microconglomerate layers, being scarce in the marls and lutites (PuértolasPascual et al., 2012). The base of the sandstones has abundant hadrosaurid footprints (Vila et al., 2013). The fossil vertebrate association recovered from these stratigraphic levels is composed of dinosaurs, mainly represented by fragmentary hadrosaurid bones, remains of sauropod titanosaurs, indeterminate theropods and possible birds, chelonians, and the eusuchian crocodile Allodaposuchus subjuniperus (CruzadoCaballero et al., 2012; Puértolas-Pascual et al., 2012; 2013; Vila et al., 2012; 2013). The former includes a mixture of differently sized elements, suggesting the presence of small and large hadrosaurids. Up to date, four sites have yielded the diminutive hadrosaurid material studied in this work: Barranco de Serraduy 2, 4, Amor 1, Color 3 and Dolor 3. Barranco de Serraduy 2 is located in the grey unit; the other sites are in the lower red unit (Cruzado-Caballero et al., 2012). These fossil localities have been correlated with the dinosaur sites at Arén, which are dated as Late Maastrichtian in age (Riera et al., 2009; Pereda-Suberbiola et al., 2009b; Puértolas-Pascual et al., 2012).

\section{Materials and methods}

The fossil material selected for this study comprises small vertebrae, including a partial sacrum, and fragmentary long bones of small-sized hadrosaurids (Fig. 2). The specimens were found scattered over neighbouring outcrops, but come from a relatively narrow stratigraphic level. We assume that the bones probably belong to a single population. The material is housed in the Museo de Ciencias Naturales de la Universidad de Zaragoza (MPZ). 

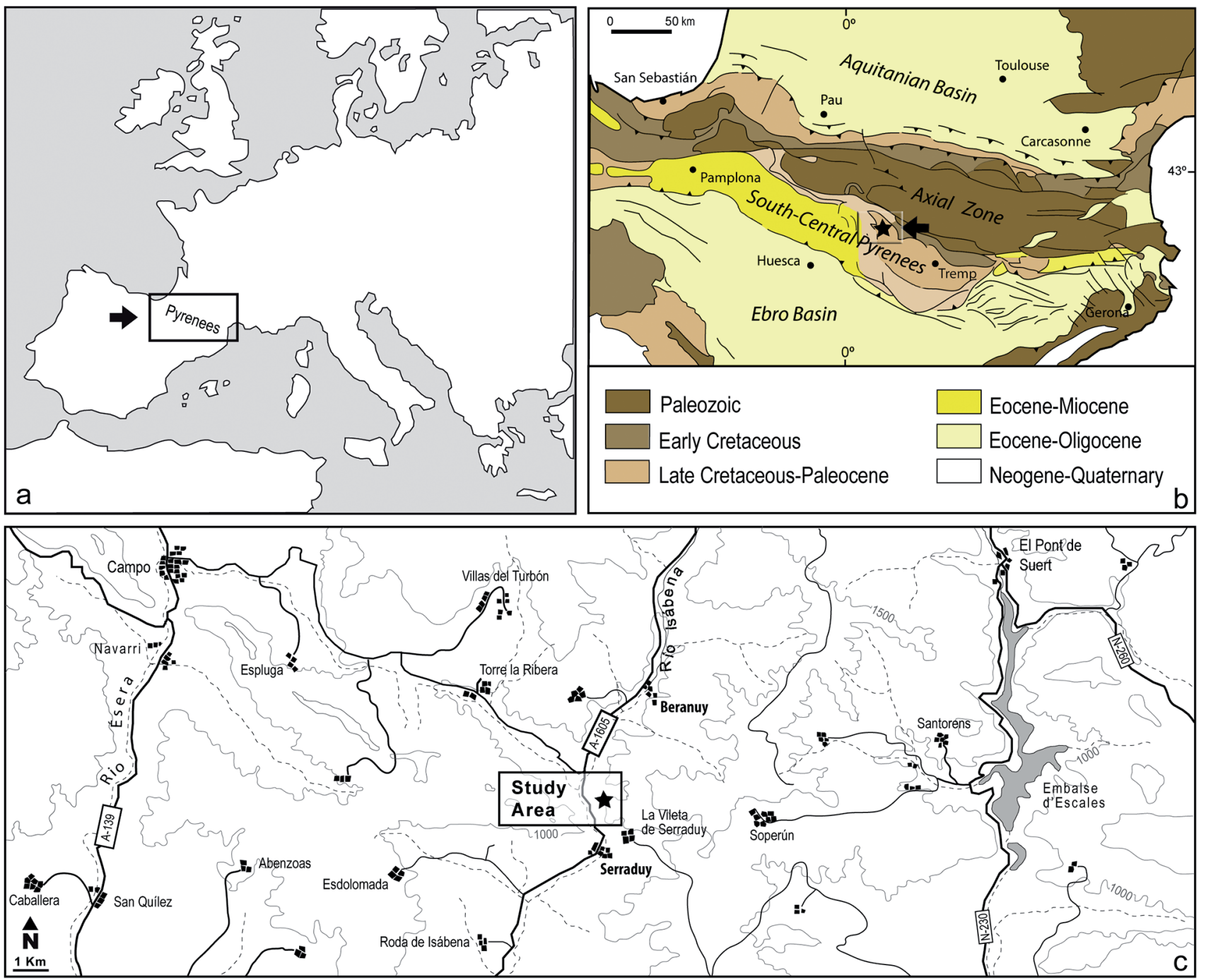

Fig. 1.- Location maps of the fossil localities (stars) where the hadrosaurid specimens were collected. A, general view of the location of the Pyrenees in the Iberian Peninsula. B, geological map of the Pyrenean region showing the area where fieldwork was undertaken. Inset shows the position of the detailed topographic map (C).

For histological analysis, the specimens were cut with a low speed diamond saw. The samples were embedded in resin and prepared for thin sections following the standard hard tissue histological techniques outlined by Chinsamy and Raath (1992). The thin sections obtained were examined under ordinary and cross-polarized light with a petrographic microscope (Olympus BXTR BX40) equipped with a digital camera (Olympus Camedia C-5060). Captured images were edited with Adobe $\subset$ Photoshop CS5 $\odot$.

In this paper, the hadrosauroid are considered as the group of iguanodontoid dinosaurs more closely related to Parasaurolophus than to Iguanodon (sensu Sereno 1986, 1998; You et al., 2003). The definition used for the Hadrosauridae family is the established by Weishampel et al. (1993), slightly modified by Horner et al. (2004). In this definition, the Hadrosauridae clade consists of the most recent common ancestor of Telmatosaurus and Parasaurolophus plus all its descendants. The Euhadrosauria are considered as the group of lambeosaurines and hadrosaurines (Weishampel et al., 1993).

\section{Osteology}

\subsection{Axial skeleton}

Several more or less complete diminutive vertebrae with mostly fused neural arches were recovered. The studied material includes a cervical centrum with both pedicles fused to it (MPZ 2013/374), a small dorsal vertebra with an almost complete neural arch including the neural spine (MPZ 2013/373), a partial sacrum (MPZ2013/366) and eight caudal vertebrae (MPZ 2013/ 367 to 372, MPZ2013/385) (Fig. 3). The vertebral elements exhibit the typical features seen in the vertebrae of other hadrosaurids. The most relevant feature is the complete closure of the sutures between the centrum and the neural arch in all of the specimens.

The cervical vertebra (MPZ 2013/374; Fig. 3a-b) is anteroposteriorly shorter than deep and wide. The centrum is heartshaped in cranial and caudal view, and moderately opisthocoelous. The neural arch is broken above the neurocentral 


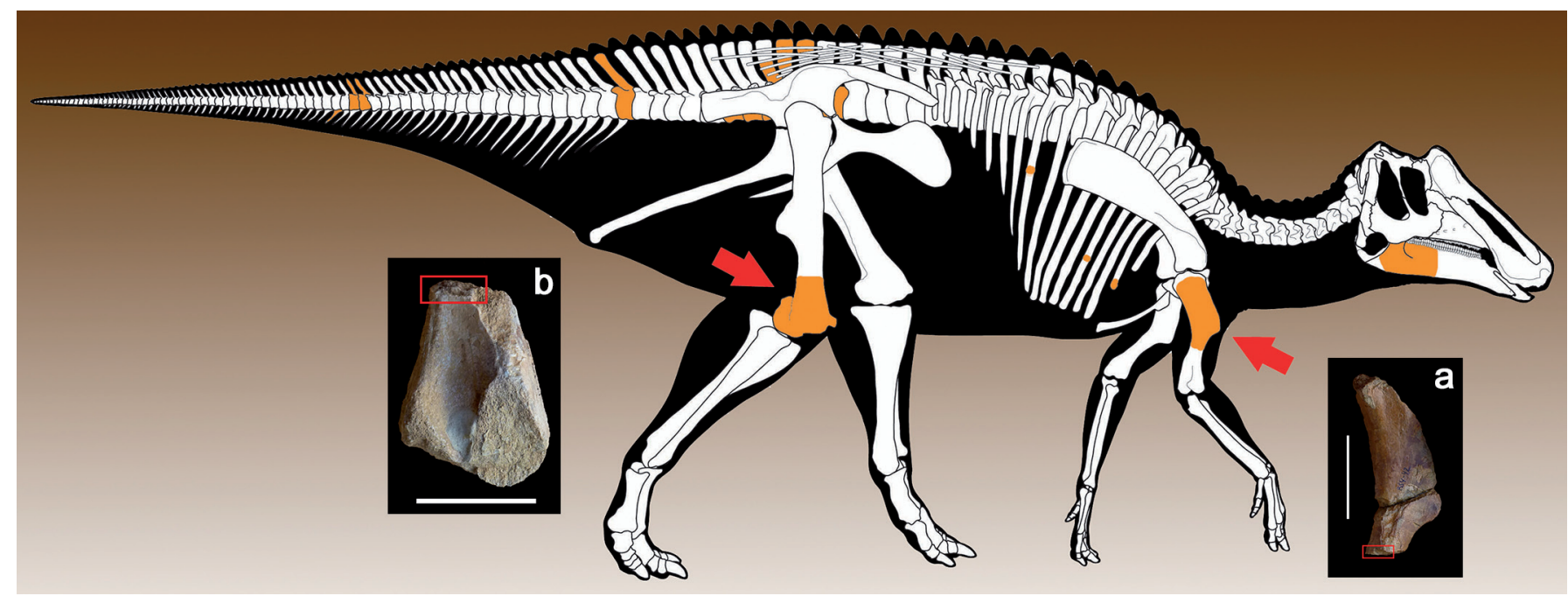

Fig. 2.- Location of the recovered elements using a skeletal reconstruction of Prosaurolophus maximus based on MOR 787 (modified from McGarrity et al., 2013). The recovered material (highlighted) comprises mostly disarticulated, fragmentary bones. One partial humerus (a), a fragmentary femur (b), and several rib fragments were selected for histological analysis. Scale bar $=5 \mathrm{~cm}$.

suture, and two stout pedicles remain fused to the centrum. Most of the external layer of bone is missing due to abrasion, so the spongy bone is exposed.

Only one dorsal vertebra has been recovered (MPZ 2013/373; Fig. 3c). The heart-shaped articular facet indicates that this element is probably an anterior dorsal vertebra. The centrum is more dorsoventrally compressed and anteroposteriorly longer than that of the cervical MPZ 2013/374, but retains the heart-shaped outline. The transverse processes and the articular facets of the prezygapophyses are eroded. The neural arch is high and the neural spine, almost complete, is a subrectangular lamina in lateral view, dorsocaudally directed. The neural spine is more than twice as tall as the centrum. As in the other specimens, the neurocentral sutural fusion between the centrum and neural arch is complete.

An articulated but incomplete sacrum, which comprises four coossified central vertebrae fused through their articular surfaces, was also recovered (MPZ2013/366; Fig. 3d,e). The centra are platycoelous and preserve the hexagonal-shaped outline seen in the caudal series. The sacrum is badly eroded, but the unions between the transverse processes and the sacral ribs are still visible. There is no evidence of a still open neurocentral suture between the pedicles and the lateral surfaces of the centra. The sacral vertebrae also have completely closed articular sutures. These osteological features suggest that MPZ2013/366 is not from a young individual.

Eight caudal vertebrae have been recovered, showing the morphology of the anterior, middle and middle-posterior portion of the tail. All the centra are platycoelous or slightly amphicoelous with hexagonal articular surfaces. The lateral surfaces are anteroposteriorly concave with expanded ends. The ventral margins bear stout facets for the insertion of the haemal arches. The anterior caudals (Fig. 3g-h) are anteroposteriorly shorter and higher than the middle and more posterior caudals (Fig.3f, i-j). The neural arches, when preserved, are low, provided with neural spines that are progressively more posteriorly oriented along the series. Although several of these vertebrae present intense abrasion in the outer surface, they preserve their neural arches complete or fragmentary, with completely closed neurocentral sutures, a typical character of adult individuals. Only the caudal centrum MPZ 2013/369 exhibits a faint suture line with the neural arch along the full length of one lateral side, suggesting that this individual may not have reached full somatic maturity.

Several small fragments of diminutive ribs were recovered together with the vertebral elements. They were used in the histological study.

\section{Bone histology}

Given that the vertebral elements were not suitable for a useful histological analysis due to their abraded condition, just two identifiable long bones (humerus and femur) and a number of fragmentary ribs were selected for histological examination.

\subsection{Humerus}

MPZ2013/365 is a right humerus which lacks most of the diaphyseal shaft and exhibits an abraded proximal end (Fig. 2). The length of the deltopectoral crest measures ca. $95 \mathrm{~mm}$. According to Prieto-Márquez (2008), the estimated length of the bone would thus be comprised between 156 and $195 \mathrm{~mm}$. This would make specimen MPZ2013/365 the smallest nonhatchling hadrosaurid humerus reported in Europe to date, comparable in size to that of a juvenile Parasaurolophus from North America of approximately $25 \%$ of its adult body length (Farke et al., 2013). This remain is the most interest- 


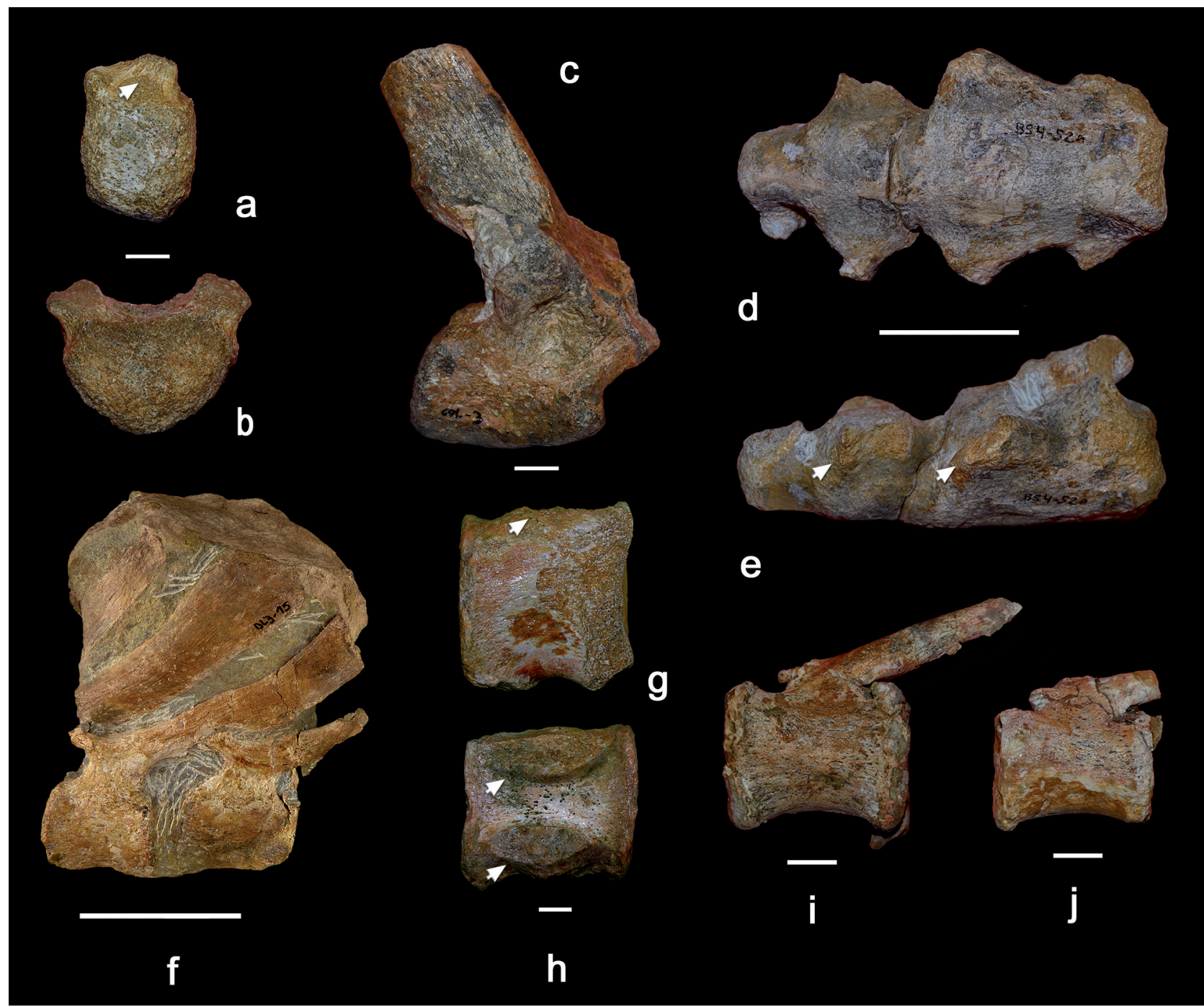

Fig. 3.- Hadrosaurid remains from the late Maastrichtian Tremp Formation in Huesca Province (Spain). a-b, cervical vertebra (MPZ 2013/374) in left lateral (a) and caudal (b) views. c, dorsal vertebra (MPZ 2013/373) in right lateral view. d-e, sacrum (MPZ 2013/366) in ventral (d) and right lateral (e) views. f, mid-caudal vertebra (MPZ 2013-371) in left lateral view. g-h, caudal vertebra (MPZ 2013369) in right lateral (g) and dorsal (h) views. i, posterior caudal vertebra (MPZ 2013/385) in left lateral view. j, posterior caudal vertebra (MPZ 2013-367) in left lateral view. Arrows point to the position of the bases of the pedicels (a,g,h) and the sutural surface for sacral ribs (e). Scale for a-c, $g-j=10 \mathrm{~mm}$. Scale for $\mathrm{d}-\mathrm{f}=50 \mathrm{~mm}$.

ing specimen from a systematic point of view. The humerus exhibits a well-developed anteroposteriorly deltopectoral crest which extends more than half way down the shaft. This feature is characteristic of euhadrosaurian hadrosaurids and unique in basal hadrosauroids (Horner et al., 2004).

The bone was sectioned through its preserved distal end (the proximal part of the diaphysis), so an almost complete section of the shaft was obtained. The thickness of the compacta ranges between 3 and $7 \mathrm{~mm}$, and encloses a large medullary region completely filled by thin trabeculae, composed of secondary cancellous bone. This humerus, although apparently well preserved externally, is considerably damaged internally by haematitic overgrowths that obliterate most of the cortex, fill the fissures and vascular spaces, and coat the internal surface of the trabeculae and the erosional rooms (Figs. 4, 5a-b).
An examination of the cortex reveals two distinct regions: the inner cortex exhibits an extensive process of cortical remodelling by secondary osteons, resulting in a dense Haversian tissue that obliterates almost completely the primary complex of the cortex (Figs. 4, 5c). In this part, only remnants of the primary periosteal bone remain visible. The transition between the deep cortex and the medullary cavity is abruptly marked by large erosion rooms, which denote the expansion of the medullary cavity. The outer cortex (1-2 mm in thickness), by contrast, is almost entirely composed of laminar fibro-lamellar bone (Fig. 5b). It constitutes the primary periosteal tissue not obliterated by Haversian remodelling. The laminar organization of the vascular architecture varies locally to a subplexiform type: although there is a prevalence of longitudinal and circular canals, arranged in circumferential rows, certain areas exhibit the presence of radial vessels. The 


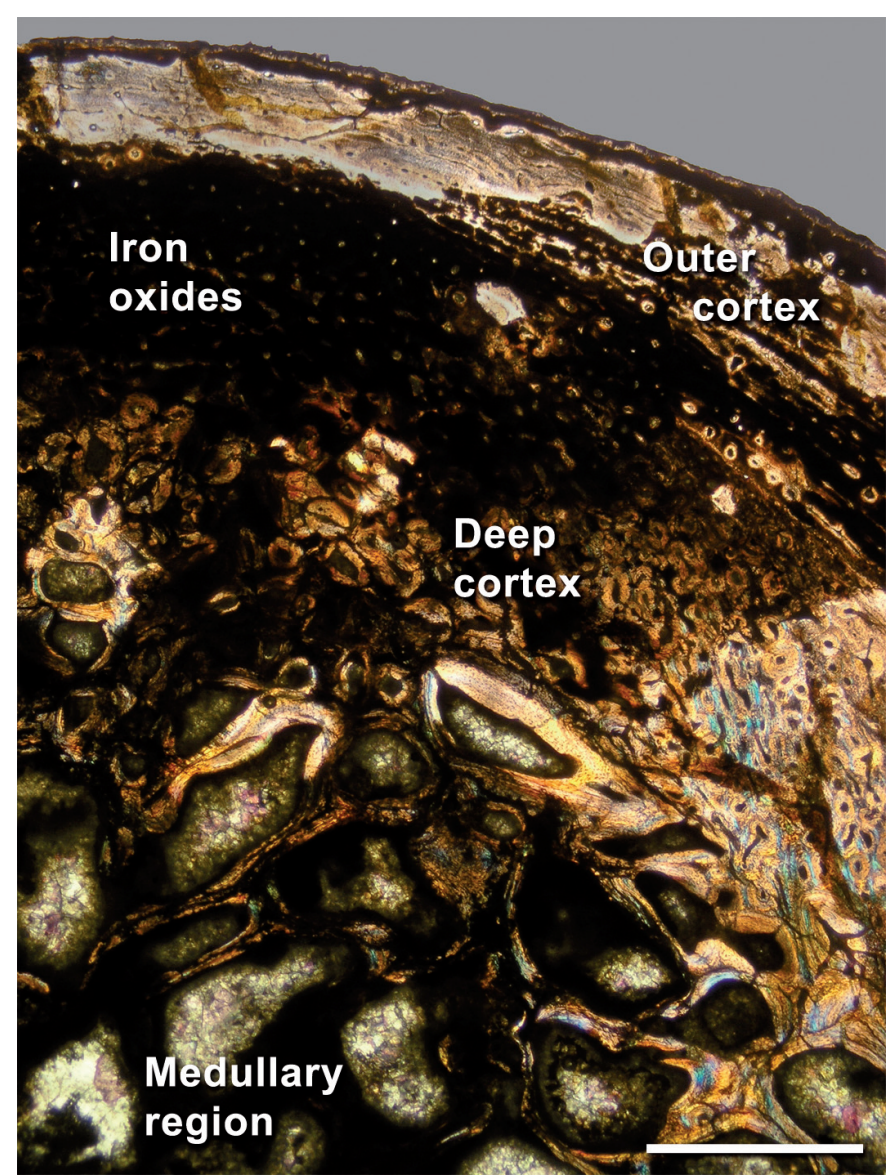

Fig. 4.- Diaphyseal transverse thin section of the humerus MPZ 2013/365 showing iron oxides coating the cavities of the medullary region and extending to the outer cortex. Most of the inner and middle cortex is heavily remodeled by dense Haversian bone. Only the outermost cortex exhibits remains of the primary periosteal tissue. Polarized light with lambda compensator. Scale bar $=1 \mathrm{~mm}$.

vascular spaces are narrow and surrounded by a thick coating of lamellar bone, indicating the maturity of the primary osteons. The woven bone matrix of the laminar tissue grades outwardly into a parallel-fibred or even lamellar organization which retains the laminar vascularization, resulting in a pseudolamellar bone tissue (Bailleul et al., 2011). This type of slow-growing bone tissue has been observed in mature specimens of other Late Cretaceous dinosaurs (Company, 2011; Klein et al., 2012). Vascular density decreases towards the bone periphery and no vascular spaces are open to the bone surface, which is considered to be evidence of a slow-down in active growth. Growth marks, even if present, cannot be observed due to the poor microstructural preservation, but their presence should not be ruled out. Scarce secondary osteons are dispersed throughout the outer cortex (Fig. 5b)

\subsection{Femur}

MPZ2013/363 is a distal femur that only preserves a damaged condylar region and the distal-most part of the diaphysis (Fig. 2). The bone is badly eroded in the distal end, but preserves the compacta in the diaphysis. The transverse thin section of the bone shaft exhibits a similar picture to that described above. The inner and middle cortex is heavily remodelled by Haversian bone resulting from the secondary reconstruction of the primary periosteal bone. The secondary osteons of the deepest region of the cortex have wide open vascular spaces suggesting that they are not fully developed. The presence of large erosional spaces in the perimedullary region indicates active enlargement of the medullar cavity when the animal demised. The outer cortex is dominated by the primary periosteal bone of the laminar fibro-lamellar type with more frequent anastomoses than in humerus MPZ2013/365. The density of longitudinal and circular canals clearly diminishes toward the outer periphery, where they become very sparse, and the bone organization grades to a parallel-fibred tissue, indicating the well-known reduction in the rate of bone deposition related with ageing (Fig. 5d). Isolated secondary osteons reach the cortical periphery. The intense remodellation of the primary bone again prevents the correct visualization of cortical growth lines.

\subsection{Rib fragments}

Several rib fragments were thin-sectioned for histological study, but only one specimen is of interest from an ontogenetic point of view. The fragmentary rib MPZ2013/364 exhibits a strongly remodelled cortex with a thin peripheral layer of poorly vascularized primary bone with a set of closely spaced lines of arrested growth (LAGs) which constitute the EFS, the histological signal of growth cessation (Fig. 5e). Where the secondary reconstruction is less invasive, two additional LAGs are visible in the middle cortex (Fig. 5f)

\section{Discussion}

The hadrosauroid fauna of the latest Maastrichtian in the Ibero-Armorican Island is significantly diverse and palaeobiogeographically related to other Laurasian taxa; at least five different hadrosauroids are known, none of which is small in size (Pereda-Suberbiola et al., 2009b; Prieto-Márquez et al., 2013; Cruzado-Caballero et al., 2014)

The material from Serraduy del Pon and Beranuy is unique in its small size. The vertebral material recovered (MPZ2013/362, MPZ2013/366 to 372) is considered to be from adult individuals on the basis of the complete fusion between the neural arches and the centra. The sacrum (MPZ2013/366) presumably belongs to an adult individual as well, because of the fused state of the vertebral elements, which preserve attached remains of the neural arches and sacral ribs. The poor state of preservation of the external surface of these bones prevents a histological study that might have confirmed this assumption.

As for the long bones (MPZ2013/363 to 365), these elements would be considered to be from juvenile animals if their small size alone were taken into account. However, the his- 



Fig. 5.- Bone histology of the hadrosaurid remains from the Late Maastrichtian Tremp Formation in Huesca Province (Spain). a-c, diaphyseal transverse section of the humerus MPZ 2013/365. a, general view of the middle and outer cortex showing laminar fibrolamellar bone tissue (bottom) grading upwards to pseudolamellar bone. Note that iron oxides (black areas) obliterate most of the original bone microstructure. $b$, magnification of the outermost cortex showing a pseudolamellar arrangement of the primary bone tissue. The vascular network is predominantly laminar to locally longitudinal. Vascular spaces of the primary osteons are full filled, indicating that the bone corresponds to a mature individual. c, detail of the deep cortex showing extensive development of dense Haversian bone. Remodelling extends through most of the deep and middle cortex. Large erosion rooms that mark the maximum expansion of the medullary cavity can be seen at the bottom of the picture. $d$, transverse section of femur MPZ2013/363 showing a magnification of the outermost cortex. Note the practically avascular peripheral (subperiosteal) region of the bone, suggesting a slow-down in bone deposition related to skeletal maturation. e-f, transverse thin section of rib MPZ2013/364. e, detail of the outer cortex showing the presence of the external fundamental system (EFS) at the bone periphery, indicating that the animal reached its maximum size and growth plateau. f, two distinct LAGs are clearly visible in the unremodelled areas, indicating that the animal was, at least, three years old when demised. Abbreviations: lvc, longitudinal vascular canals; so, secondary osteons. Arrowheads indicate the position of EFS (e) and lines of arrested growth (f). Scale bar $=1 \mathrm{~mm}$ in a, c. Scale bar $=0.5 \mathrm{~mm}$ in b, d-f. 
tological analysis detected a number of features in the bone microstructure that are exclusive to adult individuals. Certainly, none of the sampled specimens belong to a young animal, since no "juvenile" tissues were observed in the sections. All the bones exhibit a mature histomorphology, characterized at least by a combination of three or more of the following characters: (i) extensive remodelling of the primary cortex by dense Haversian bone; (ii) presence of an outermost layer of highly organized, slow-growing primary bone, poorly vascular, with mature primary osteons; (iii) presence of growth rings which denote that the animal reached sexual maturity and lived for years; (iv) presence of a nonvascularized external fundamental system (EFS) at the periosteal surface, and (v) the presence of a greatly expanded medullar cavity lined by endosteal bone (Horner et al., 1999; Chinsamy-Turan 2005 and references therein; Klein and Sander, 2008).

Secondary remodelling of the primary bone by dense Haversian tissue takes place in young adults and progress through ontogeny. The presence of peripheral, poorly vascularized (i. e., slow-growing) bone tissue in bones, and the cessation of the expansion of the medullary cavity are clear signals of an individual approaching somatic maturity, which in tetrapods takes place at advanced stages of the animal's life history. The presence of the EFS, visible only in the bones of skeletally mature individuals, indicates that the animal had reached its maximum size at the time of death (Chinsamy and Hillenius, 2004; Chinsamy-Turan, 2005; Reid, 2012 and references therein).

None of the limb bones analysed exhibit the presence of the external fundamental system (EFS) in the outermost cortex, which is the most evident histological signal of growth cessation at maturity. Nevertheless, this structure is not always recorded in fossil bones. The outer bone surface, which contains the EFS, may easily disappear by weathering, bone abrasion or in the preparation process. Indeed, this peripheral structure is only visible in one of the periosteal margins of

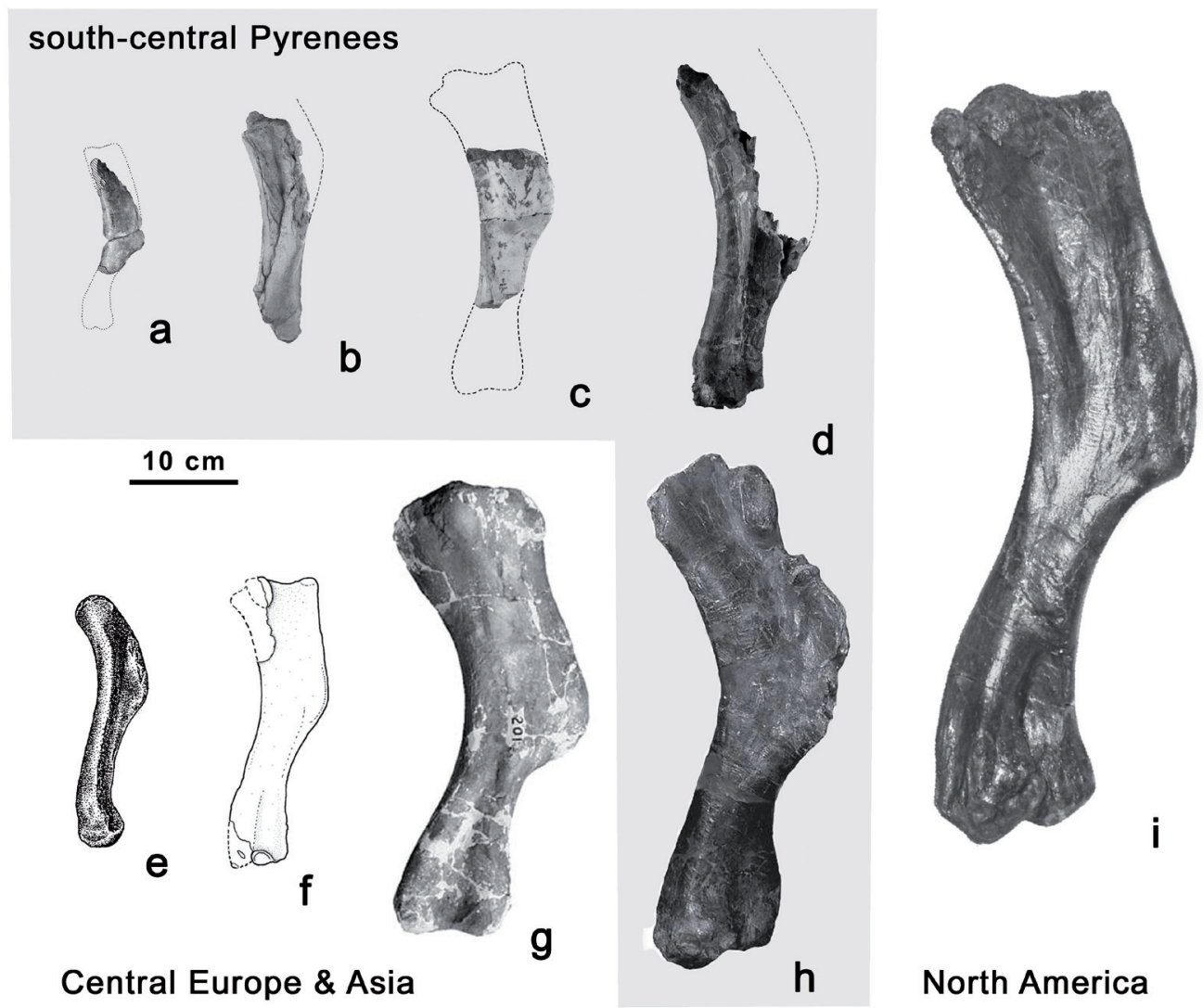

Fig. 6.- Size comparison of hadrosaurid humeri from the south-central Pyrenees (above), Eurasia and North America. a: Serraduy hadrosaur, left humerus (MPZ 2013/365) in caudal view (reversed), Huesca Province (Spain). b: Euhadrosauridae indet. left humerus (BLA 1/196) in caudal view, Huesca Province (Spain). c: Euhadrosauridae indet. left humerus (BLA 5/8) in caudal view, Huesca Province (Spain). d: Euhadrosauridae indet. right humerus (BLA 2b/2) in cranial view (reversed), Huesca Province (Spain). e: Telmatosaurus transsylvanicus, right humerus (Mafi Ob. 3126) in cranial view, Haţeg Basin (Romania). f: Tethyshadros insularis, right humerus (SC 57021) in caudal view, Trieste (Italy). g: Sahaliyania elunchunorum, right humerus (GMH W201) in caudal view, Heilongjiang Province (China). h: Pararhabdodon isonensis, left humerus (IPS SRA 15) in craniomedial view, Lleida Province (Spain). i: Gryposaurus latidens left humerus (AMNH FARB 5465) in anteromedial view, Two Medicine Formation (Montana, USA). For ease of comparison, figures a and $d$ are reversed. Reconstructions are speculative. b-d taken from Cruzado-Caballero (2012, fig. 4.102); e taken from Weishampel et al. (1993, fig. 5C); f taken from Dalla Vecchia (2009, fig. 6); g taken from Godefroit et al. (2008, fig. 9A1); h taken from Prieto-Márquez et al. (2006, fig. 6C); i taken from Prieto-Márquez (2012, fig. 11A). 
the rib MPZ 2013/364, and is not recorded in the opposite one. Moreover, the animals may simply die before reaching somatic maturity, which is frequent in wildlife (Skalski et al., 2005; Stein et al., 2010; Company, 2011; Klein et al., 2012).

In summary, the osteologic and histological studies suggest that the small hadrosaurid bones from the sites of Serraduy del Pon and Beranuy pertain to individuals that almost reached total somatic maturity (i.e., final adult size). As regards the most complete and diagnostic element in the Serraduy assemblage, the humerus MPZ2013/365, the estimated length of the element ranges from $53.4 \%$ to $66.7 \%$ of the length of the humerus of Tethyshadros insularis (Dalla Vecchia, 2009), and between $68.7 \%$ and $85 \%$ of the length of the humerus of Telmatosaurus transsylvanicus (Grigorescu and Csiki, 2006), which were the smallest hadrosaurids previously described in the Maastrichtian of the European Archipelago. With respect to the Late Maastrichtian lambeosaurine faunas of Europe, the Serraduy humerus measures only between $40.5 \%$ and $32.5 \%$ of the length of the humerus of Pararhabdodon isonensis (Casanovas-Cladellas et al., 1987), and is as much as 19.6\% smaller than the juvenile humerus of Canardia garonnensis (Prieto-Márquez et al., 2013). Direct comparison with incomplete humeri from other European hadrosaurids (see data in Cruzado-Caballero, 2012) also confirms the reduced size of the Serraduy taxon. All in all, excluding the hatchling T. transsylvanicus humeri from Romania (Grigorescu and Csiki, 2006), this element is the smallest humerus known from an adult hadrosaurid of the entire Late Cretaceous of Europe (Fig. 6).

At present, various latest Cretaceous localities in Europe have yielded a diverse fauna composed of small hadrosaurid taxa (T. transsylvanicus, $T$. insularis, $C$. garonnensis) together with medium-to-large forms (P. isonensis, B. canudoi, A. ardevoli, and indeterminate hadrosaurids represented by incomplete remains). Recently, the discovery of gigantic lambeosaurine specimens in sediments of similar age (Fondevilla et al., 2013) has further complicated the situation. This wide range in the size of related taxa is difficult to explain in analogous paleogeographic scenarios of isolated islands, where all the faunal elements would be subject to similar evolutionary pressures in resource-limited isolated ecosystems. It is reasonable to think that there could be a mixture of migrant faunas from other parts of Laurasia with the autochthonous European elements that evolved on the islands in the periods where a faunal interchange between isolated landmasses was not possible. The new small hadrosaurid described in this paper could be one of these relict taxa.

\section{Conclusions}

The bone histology and osteological features of the diminutive bones from indeterminate hadrosaurids recovered from the nonmarine sediments of the Late Maastrichtian Tremp Formation, near the villages of Serraduy del Pon and Beranuy, reveal that these bones pertain neither to hatchling nor to juvenile individuals. Certain osteological features observed in the axial elements (vertebral centra with fused neural arches, fused partial sacrum) suggest that these remains belong to adult individuals of small body size. This observation is further corroborated by the results of a histological analysis of the long bones. Even though only one of the examined elements seems to belong to a fully-grown individual (a fragment of rib MPZ 2013/364), the histological analysis suggests that the remainder bones represent small-bodied adult hadrosaurids approaching their final body size. They are undoubtedly not the juvenile forms of the larger hadrosaurid taxa described in other localities of the region (Cruzado-Caballero, 2012) and will represent a new undescribed hadrosaurid taxon of diminutive size.

\section{Acknowledgements}

This paper forms part of the projects CGL2010-16447, CGL2010-18851/BTE and CGL2013-47521-P, subsidized by the Spanish Ministerio de Economía y Competitividad and the European Regional Development Fund. In addition the Government of Aragón ("Grupos Consolidados" and "Dirección General de Patrimonio Cultural") has subsidized the fieldwork. The second author received a postdoctoral grant from the Ministerio de Ciencia, Tecnología e Innovación Productiva del Consejo Nacional de Investigaciones Científicas y Técnicas (CONICET). The study of the specimens housed at the NHM (London) has been suported by a study grant funded by the Caja de Ahorros de la Inmaculada (Zaragoza) to the second author in 2006. The manuscript has greatly benefited from reviews by Edina Prondvai (MTA-ELTE Lendület Dinosaur Research Group, Budapest) and David B. Weishampel (Johns Hopkins University - School of Medicine, Baltimore). Special thanks also are owed to J.I. RuizOmeñaca (Museo Jurásico de Asturias-MUJA, Colunga) and Xabier Pereda-Suberbiola (Universidad del País Vasco, UPV/ EHU, Bilbao) for providing helpful information on Nopcsa's work. Rupert Glasgow corrected the English text.

\section{References}

Bailleul, A., Ségalen, L., Buscalioni, A.D., Cambra-Moo, O., Cubo, J. (2011): Palaeohistology and preservation of tetrapods from Las Hoyas (Lower Cretaceous, Spain). Comptes Rendus Palevol 10, 67380. doi: 10.1016/j.crpv.2011.05.002

Benton, M.J., Csiki, Z., Grigorescu, D., Redelstorff, R., Sander, P.M., Stein, K., Weishampel, D.B. (2010): Dinosaurs and the island rule: The dwarfed dinosaurs from Haţeg Island. Palaeogeography, $\mathrm{Pa}$ laeoclimatology, Palaeoecology 293, 438-454. doi:10.1016/j. palaeo.2010.01.026

Blakey, R.C. (2001): Late Cretaceous Paleogeographic Globe: Regional paleogeographic views of Earth History. University of Northern Arizona Geology Department. Web Site, available from: http://jan.ucc. nau.edu/-rcb7/globaltext.html.

Casanovas-Cladellas, M.L., Santafé-Llopis, J.V., Sanz, J.L., Buscalioni, A. (1987): Arcosaurios (Crocodilia, Dinosauria) del Cretácico Su- 
perior de la Conca de Tremp (Lleida, España). Estudios geológicos volumen extraordinario Galve- Tremp, 95-110.

Casanovas-Cladellas, M.L., Santafé-Llopis, J.V., Isidro-Llorens, A. (1993): Pararhabdodon isonense n. gen. n. sp. (Dinosauria). estudio mofológico, radiotomográfico y consideraciones biomecanicas. Paleontologia i Evolució 26-27, 121-131.

Chinsamy-Turan, A. (2005): The microstructure of dinosaur bone: deciphering biology with fine-scale techniques. Johns Hopkins University Press, Baltimore, $216 \mathrm{p}$.

Chinsamy, A., Hillenius, W.J. (2004): Physiology of nonavian dinosaurs. In: D.B. Weishampel, P. Dodson, H. Osmólska (eds.), The Dinosauria, $2^{\text {nd }}$ edition, University of California Press, Berkeley, pp. 643-659.

Chinsamy, A., Raath, M.A. (1992): Preparation of fossil bone for histological examination. Palaeontologia Africana 29, 39-44.

Company, J. (2011): Bone histology of the titanosaur Lirainosaurus astibiae (Dinosauria, Sauropoda) from the Latest Cretaceous of Spain. Naturwissenschaften 98, 67-78. doi: 10.1007/s00114-010-0742-3

Cruzado-Caballero, P. (2012): Restos directos de dinosaurios hadrosáuridos (Ornithopoda, Hadrosauridae) del Maastrichtiense superior (Cretácico Superior) de Arén (Huesca). Unpublished Doctoral Thesis, Universidad de Zaragoza, Zaragoza, $410 \mathrm{p}$.

Cruzado-Caballero, P., Pereda-Suberbiola, X., Ignacio Ruiz-Omeñaca, J.I. (2010): Blasisaurus canudoi gen. et sp. nov., a new lambeosaurine dinosaur (Hadrosauridae) from the Latest Cretaceous of Arén (Huesca, Spain). Canadian Journal of Earth Sciences 47, 1507-1517. doi:10.1139/TE10-081

Cruzado-Caballero, P., Puértolas-Pascual, E., Canudo, J.I., Castanera, D., Gasca, J.M., Moreno-Azanza, M. (2012): New hadrosaur remains from the Late Maastrichtian of Huesca (NE Spain). Abstracts 10th Annual Meeting of the European Association of Vertebrate Palaeontologists. Teruel. Fundamental 20, 45-48.

Cruzado-Caballero, P., Ruiz-Omeñaca, J.I., Gaete, R., Riera, V., Oms, O., Canudo, J.I. (2014): A new hadrosaurid dentary from the latest Maastrichtian of the Pyrenees (north Spain) and the high diversity of the duck-billed dinosaurs of the Ibero-Armorican Realm at the very end of the Cretaceous. Historical Biology 26, 619-630. doi: 10.1080/08912963.2013.822867

Dalla Vecchia, F.M. (2009): Tethyshadros insularis, a new hadrosauroid dinosaur (Ornithischa) from the Upper Cretaceous of Italy. Journal of Vertebrate Paleontology 29, 1100-1116. doi: 10.1671/039.029.0428

Farke, A.A., Chok, D.J., Herrero, A., Scolieri, B., Werning, S. (2013): Ontogeny in the tube-crested dinosaur Parasaurolophus (Hadrosauridae) and heterochrony in hadrosaurids. PeerJ 1, e182. doi: 10.7717/ peerj. 182

Fondevilla, V., Razzolini, N.L., Gaete, R., Pellicer-Mir, X., Galobart, A. (2013): XL Hadrosaurids of Tremp basin: the Costa de Les Solanes site (Late Maastrichtian, northeast of the Iberian Peninsula). Abstracts VI Jornadas Internacionales sobre Dinosaurios y su entorno, Salas de los Infantes, Burgos, pp. 67-68.

Godefroit, P., Hay, S., Yu, T., Lauters, P. (2008): New hadrosaurid dinosaurs from the uppermost Cretaceous of northeastern China. Acta Palaeontologica Polonica 53, 47-74. doi:10.4202/app.2008.0103

Grigorescu, D., Csiki, Z. (2006): Ontogenetic development of Telmatosaurus transsylvanicus (Ornitischia: Hadrosauria) from the Maastrichtian of the Haţeg Basin, Romania - evidence from the limb bones. Hantkeniana 5, 20-26.

Horner, J.R., Ricqlès, A. de, Padian, K. (1999): Variation in dinosaur skeletochronology indicators: implications for age assessment and physiology. Paleobiology 25, 295-304.

Horner, J.R., Weishampel, D.B., Forster, C.A. (2004): Hadrosauridae. In: D.B. Weishampel, P. Dodson, H. Osmólska (eds.), The Dinosauria, $2^{\text {nd }}$ edition, University of California Press, Berkeley, pp. 438-463.

Klein, N., Sander, P.M. (2008): Ontogenetic stages in the long bone histology of sauropod dinosaurs. Paleobiology 34, 247-263. doi: 10.1666/0094-8373(2008)034[0247:ositlb]2.0.co;2

Klein, N., Martin Sander, P., Stein, K., Le Loeuff, J., Carballido, J. L., Buffetaut, E. (2012): Modified laminar bone in Ampelosaurus atacis and other titanosaurs (Sauropoda): implications for life history and physiology. PLOS ONE 7(5), e36907. doi:10.1371/journal. pone.0036907

Le Loeuff, J. (1991): The Campano-Maastrichtian vertebrate faunas from Southern Europe and their relationships with other faunas in the world: Palaeobiogeographical implications. Cretaceous Research, 12, 93-114. doi : 10.1016/S0195-6671(05)80019-9

Le Loeuff, J. (1995): Ampelosaurus atacis (nov. gen., nov. sp.), un nouveau Titanosauridae (Dinosauria, Sauropoda) du Crétacé supérieur de la Haute Vallée de l'Aude (France). Comptes Rendus de l'Academie des Sciences Paris (IIa) 321, 693-699.

Le Loeuff, J. (2005): Romanian Late Cretaceous dinosaurs: big dwarfs or small giants? Historical Biology 17, 15-17. doi : $10.1080 / 08912960500376210$

McGarrity, C.T., Campione, N.E., Evans, D.C (2013): Cranial anatomy and variation in Prosaurolophus maximus (Dinosauria: Hadrosauridae). Zoological Journal of the Linnean Society 167, 531-568. doi: 10.1111/zoj.12009

Nopcsa, F. (1914): Über das Vorkommen der Dinosaurier in Siebenbürgen. Verhandlungen der zoologische-botanischen Gesellschaft 64, $12-14$.

Nopcsa, F. (1923): On the geological importance of the primitive reptilian fauna of the uppermost Cretaceous of Hungary: with a description of a new tortoise (Kallokibotium). Quarterly Journal of the Geological Society of London 79, 100-116.

Pereda-Suberbiola, X. (1999): Ankylosaurian dinosaur remains from the Upper Cretaceous of Laño (Iberian Peninsula). Estudios del Museo de Ciencias Naturales de Alava 14 (Número especial 1), 273-288.

Pereda-Suberbiola, X., Galton, P. (2009): Dwarf dinosaurs in the latest Cretaceous of Europe. In: Colectivo Arqueológico-Paleontologógico Salense (ed.), Actas IV Jornadas Internacionales sobre Paleontología de Dinosaurios y su Entorno, Salas de los Infantes, Burgos, pp. 263-272.

Pereda-Suberbiola, X., Canudo, J.I., Company, J., Cruzado-Caballero, P., Ruiz-Omeñaca, J.I. (2009a): Hadrosauroid dinosaurs from the Latest Cretaceous of the Iberian Peninsula. Journal of Vertebrate Paleontology 29, 946-951. doi: 10.1671/039.029.0317

Pereda-Suberbiola, X., Canudo, J.I., Cruzado-Caballero, P., Barco, J.L., López-Martínez, N.,Oms, O., Ruiz-Omeñaca, J.I. (2009b): The last hadrosaurid dinosaurs of Europe: A new lambeosaurine from the uppermost Cretaceous of Arén (Huesca, Spain). Comptes Rendus Palevol 8, 559-572. doi:10.1016/j.crpv.2009.05.002

Philip, J., Floquet, M., Platel, J.P., Bergerat, F., Sandulescu, M., Baraboshkin, E., Amon, E.O., Poisson, A., Guiraud, R., Vaslet, D., Le Nindre, Y., Ziegler, M., Bouaziz, S., Guezou, J.C. (2000): Map 16 - Late Maastrichtian (69.5-65 Ma). In: J. Dercourt, M. Gaetani, B. Vrielynck, E. Barrier, B. Biju-Duval, M. F. Brunet, J. P. Cadet, S. Crasquin, M. Sandulescu (eds.), Atlas Péri-Téthys, Palaeogeographical maps, CCGM/CGMW, Paris.

Prieto-Márquez, A. (2008): Phylogeny and historical biogeography of hadrosaurid dinosaurs. Ph.D. thesis, Florida State University, Tallahassee, Electronic Theses, Treatises and Dissertations, Paper 460, $861 \mathrm{p}$.

Prieto-Márquez, A. (2012): The skull and appendicular skeleton of Gryposaurus latidens, a saurolophine hadrosaurid (Dinosauria: Ornithopoda) from the early Campanian (Cretaceous) of Montana, USA. Canadian Journal of Earth Sciences 49, 510-532. doi:10.1139/E11-069.

Prieto-Márquez, A., Gaete, R., Rivas, G., Galobart, A., Boada, M. (2006): Hadrosauroid dinosaurs from the Late Cretaceous of Spain: Pararhabdodon isonensis revisited and Koutalisaurus kohlerorum, gen. et sp. nov. Journal of Vertebrate Paleontology 26, 929-943. doi: 
10.1671/0272-4634(2006)26[929:HDFTLC]2.0.CO;2

Prieto-Márquez, A., Dalla Vecchia, F.M., Gaete, R., Galobart, A. (2013): Diversity, relationships, and biogeography of the lambeosaurine dinosaurs from the European archipelago, with description of the New Aralosaurin Canardia garonnensis. PLoS ONE 8(7), e69835. doi:10.1371/journal.pone.0069835

Puértolas-Pascual, E., Cruzado-Caballero, P., Canudo, J.I., Gasca, J.M., Moreno-Azanza, M., Castanera, D., Parrilla, J., Ezquerro, L. (2012): Nuevos yacimientos de vertebrados del Maastrichtiense superior (Cretácico Superior) de Huesca (España). Geo-Temas 13, 269-272.

Puértolas-Pascual, E., Canudo, J. I., Moreno-Azanza, M. (2013): The eusuchian crocodylomorph Allodaposuchus subjuniperus sp. nov., a new species from the Latest Cretaceous (upper Maastrichtian) of Spain. Historical Biology 26, 91-109. doi:10.1080/08912963.2012 .763034

Reid, R.E.H. (2012): How dinosaurs grew. In: M.K. Brett-Surman, T.R. Holtz Jr., J.O. Farlow (eds.), The Complete Dinosaur, $2^{\text {nd }}$ edition, Indiana University Press, Bloomington, pp. 621-635.

Riera, V., Oms, O., Gaete, R., Galobart, A. (2009): The end-Cretaceous dinosaur succession in Europe: the Tremp Basin record (Spain). $\mathrm{Pa}$ laeogeography, Palaeoclimatology, Palaeoecology 283, 160-171. doi:10.1016/j.palaeo.2009.09.018

Sander, M.P., Mateus, O., Laven, T., Knötschke, N. (2006): Bone histology indicates insular dwarfism in a new Late Jurassic sauropod dinosaur. Nature 441, 739-741. doi: 10.1038/nature04633

Sanz, J.L., Powell, J.E., Le Loeuff, J., Martínez, R., Pereda-Suberbiola, X. (1999): Sauropod remains from the Upper Cretaceous of Laño (north central Spain). Titanosaur phylogenetic relationships. Estudios del Museo de Ciencias Naturales de Álava, 14 (Número especial 1), $235-255$.

Sereno, P.C. (1986): Phylogeny of the bird-hipped dinosaurs (order Ornithischia). National Geographic Research 2, 234-256.
Sereno, P.C. (1998): A rationale for phylogenetic definitions, with application to the higher-level taxonomy of Dinosauria. Neues Jahrbuch für Geologie und Paläontologie, Abhandlungen 210, 41-83.

Skalski, J.R., Ryding, K.E., Millspaugh, J.J. (2005): Wildlife demography: Analysis of sex, age, and count data. Academic Press, San Diego, $656 \mathrm{p}$.

Stein, K., Csiki, Z., Curry Rogers, K., Weishampel, D.B., Redelstorff, R., Carballido, J.L., Sander, P.M. (2010): Small body size and extreme cortical bone remodeling indicate phyletic dwarfism in Magyarosaurus dacus (Sauropoda: Titanosauria). Proceedings of the National Academy of Sciences 107, 9258-9263. doi:10.1073/ pnas. 1000781107

Vila, B. Galobart, A., Canudo, J. I., Le Loeuff, J., Dinarés-Turell, J., Riera, V., Oms, O., Tortosa, T., Gaete, R. (2012): The diversity of sauropod dinosaurs in the latest Cretaceous of Southwest of Europe. Palaeogeography, Palaeoclimatology, Palaeoecology 350, 19-38. doi: 10.1016/j.palaeo.2012.06.008

Vila, B., Oms, O., Fondevilla, V., Gaete, R., Galobart, A., Riera, V., Canudo, J. I. (2013): The latest succession of dinosaur tracksites in Europe: Hadrosaur ichnology, track production and palaeoenvironments. PLoS ONE 8(9), e72579. doi:10.1371/journal.pone.0072579

Weishampel, D.B., Norman, D.B., Grigorescu, D. (1993): Telmatosaurus transsylvanicus from the Late Cretaceous of Romania: the most basal hadrosaurid dinosaur. Palaeontology 36, 361-385.

Weishampel, D.B., Jianu, C.-M., Csiki, Z., Norman, D.B. (2003): Osteology and phylogeny of Zalmoxes (n. g.), an unusual euornithopod dinosaur from the latest Cretaceous of Romania. Journal of Systematic Palaeontology 1, 65-123. doi: 10.1017/S1477201903001032

You, H., Luo, Z., Shubin, N.H., Witmer, L.M., Tang, Z.,Tang, F. (2003): The earliest-known duck-billed dinosaur from deposits of late Early Cretaceous age in northwest China and hadrosaur evolution. Cretaceous Research 24, 347-355. doi: 10.1016/S0195-6671(03)00048-X 